\title{
ADHERENCE TO ANTIRETROVIRAL THERAPY AND ASSOCIATED FACTORS AMONG HIV POSITIVE ADULTS ATTENDING TREATMENT AT NEKEMTE REFERRAL HOSPITAL, WEST ETHIOPIA, 2019
}

Muktar Abadiga ( $\sim$ muktarabadiga@gmail.com )

Research article

Keywords: Adherence, Antiretroviral therapy, HIV/AIDS, Ethiopia

Posted Date: August 13th, 2019

DOI: https://doi.org/10.21203/rs.2.12737/v1

License: (c) (1) This work is licensed under a Creative Commons Attribution 4.0 International License. Read Full License 


\section{Abstract}

BACK GROUND Antiretroviral therapy has a remarkable clinical effect in decreasing the viral replication, reducing the progress of AIDS and deaths related to AIDS. The clinical outcome of ART depends on the strict adherence to antiretroviral medication. However; only a few studies have been done on the adherence status of ART and its determinant factors in Ethiopia and this study could provide an opportunity to identify obstacles to taking medication. Therefore, the purpose of this study was to assess adherence status and associated factors among HIV infected patients on ART attending Nekemte referral hospital, West Ethiopia. METHODS Institutional based cross-sectional study was conducted on 311 HIV/AIDS patients, from March 01 to March 30, 2019. The study participants were selected by simple random sampling method and were interviewed using structured questionnaires. The data were coded, checked, cleaned and entered into Epi data version 3.1 and then exported to SPSS window version 20.0 for analysis. Multivariable logistic regression was used to find the independent variables which best predict adherence. Association and statistical significance were measured using odds ratio at $95 \%$ confidence interval and p-value less than 0.05. RESULTS A total of $305 \mathrm{HIV/AIDS}$ patients were included in this study. Out of this,73.1\% were adhered to their medication. Respondent's knowledge about HIV and its treatment (AOR=8.13,95\% Cl: 3.06, 21.61), family/social support (AOR=7.36, 95\% Cl: 2.07, 26.10), adverse effects of ARV medications (AOR=5.62,95\% Cl: 2.11, 14.93), co-morbidity of other chronic illness ( $A O R=5.46,95 \% \mathrm{Cl}: 1.86,16.02)$, and family disclosure status (AOR= 5.27, 95\% $\mathrm{Cl}: 2.20,12.62)$ were significantly associated with adherence to medication among HIV/AIDS patients. CONCLUSION In this study, the level of adherence to antiretroviral therapy was found low compared to the WHO standard. The clinician should emphasize adverse drug reaction, early detect and treat co-morbidities, improve knowledge through health education, and encourage HIV/AIDS patient to disclose their HIV status.

\section{Introduction}

Human immune deficiency virus is one of a chronic disease which affects human immune systems and increases vulnerability of individuals to infections [1]. Globally, 36.7 million people were living with HIV/AIDS at the end of 2015 with approximately $70 \%$ (25.7 million) residing in Sub-Saharan Africa [2]. In Ethiopia, the Federal HIV/AIDS Prevention and Control Office (EFHAPCO) indicates that there are over 718,550 people (> $1.18 \%$ ) living with HIV [3].

Antiretroviral therapy has a remarkable clinical effect in decreasing the viral replication and viral load, reduces the progress of AIDS, and reduces deaths related to AIDS [4]. The availability of ART has essentially improved the survival rates of HIV patients, reduction of the new number of HIV infection and prevention of HIV related comorbidities [5]. The availability of this ART drugs changed the disease course to chronicity which arise the issue of adherence. However, the clinical outcome of ART depends on the strict adherence of HIV patients to antiretroviral medication. Strict adherence to antiretroviral therapy is important to decrease the multiplication of the virus and improve disease outcomes [6 \& 7]. 
Several studies indicate that $>95 \%$ adherence to therapeutic regimen is required for HIV infected patient to reach full viral suppression [8 - 11]. Maintaining over $95 \%$ adherence level is a crucial to maintain viral suppression, to minimize HIV related morbidity and mortality. In Ethiopia, the rate of adherence to ART is $88.2 \%$, which is low compared to WHO Standard [12]. Poor adherence to antiretroviral therapy reduces the effectiveness of ART and hastens viral distribution and drug resistance [13 \& 14]. Poor adherence is linked to higher mortality rates, higher rates of decrease in CD4 cell count, lower therapeutic success and increased hospital days [15]. Studies have shown that adherence to ART medication among people living with HIV/AIDS is affected by factors related to the patient, therapeutic regimen, psychosocial environment and health care related factors. Hence, factors such as socio-demographic and sociocultural factors, side effects of ARVs, ART regimes, duration on ART, and psychosocial factors such as stress, depression and anxiety have also been associated with ART adherence [16 \& 17]. It is essential to assess the number of people living with HIV/AIDS drop out of treatment programmes and factors affecting adherence to ART. Since most of the Ethiopian setting is resource limited, there are no routine assessments for ART adherence among PLHIV in Ethiopia. In addition, only a few studies have been done on the adherence status of ART and its determinant factors in Ethiopia and this study could provide an opportunity to identify obstacles to taking ART medication which may help to prevent development of drug resistance and treatment failure. Therefore, this study was aimed to assess adherence status and associated factors among HIV infected patients.

\section{Methods And Materials}

\section{STUDY SETTING AND POPULATION}

This study was conducted in Nekemte referral hospital from March 01 to March 30, 2019. Nekemte referral hospital if found in Nekemte town which is one of the largest towns found in western part of Ethiopia at about 325 kilometers from a capital city Addis Ababa. The institutional based cross-sectional study design was employed. All ART patients on treatment follow up at Nekemte referral hospital was the source population and the sampled ART patients who had treatment follow up during the study period was the study population. Patients whose ages are 18 years and above were included in this study. Patients who are eligible but not willing to take part in the study were excluded.

\section{SAMPLE SIZE DETERMINATION AND SAMPLING TECHNIQUES}

The sample size of the study was calculated using the formula for estimation of a single population proportion with the assumptions of $95 \%$ Confidence Level (CL), marginal error (d) of 0.05 . Adherence level of 0.74 (74.0 \%) was taken from previous study done in Addis Ababa [18], and by adding a nonresponse rate of $5 \%$, a total of 311 ART patients were enrolled in the study. Simple random sampling method was used to select the study participants.

\section{DATA COLLECTION TOOL AND PROCEDURES}


Data was collected using a structured questionnaire and face-to-face interview was used for data collection. The dependent variable of the study was adherence to ART and the independent variables were socio-demographic, psychosocial and medication related characteristics. Adherence status was assessed based on the number of pills reported to have been taken one month prior to the data collection period divided by the number of prescribed pills multiplied by $100 \%$. Patients who reported an intake of $\geq$ $95 \%$ of the prescribed medication were considered adherent; those with a reported intake of $<95 \%$ were classified as non-adherent [19]. Socio-demographic factors, psychosocial and medication related characteristics were measured as explanatory variables. Data was collected by three trained BSc nurses and one supervisor for duration of approximately one month.

\section{DATA PROCESSING AND ANALYSIS}

The data were coded, checked, cleaned and entered into Epi data version 3.1 and then exported to SPSS window version 20.0 for analysis. Bivariate analysis was done to find association between each independent variable with adherence. Finally, multivariable logistic regression was used to find out the independent variables which best predict adherence. Association and statistical significance were measured using odds ratio at $95 \%$ confidence interval and p-value less than 0.05 .

\section{DATA QUALITY CONTROL}

The questionnaire was translated to the local language and then translated back to English by expertise for consistency. Five percent ( $5 \%$ ) of the questionnaire was pre-tested on ART patients having treatment follow up at Gimbi general hospital which is found about 87-kilometer distance from Nekemte referral hospital. One-day training was also given for data collectors and supervisor.

\section{Results}

\section{SOCIO-DEMOGRAPHIC CHARACTERISTICS OF PARTICIPANTS}

Out of the total of 311 study participants sampled, 305 were participated; making a response rate of $98.07 \%$. From the total of 305 participants, 140 (45.9\%) were male, and $165(54.1 \%)$ were females. One hundred six, $(34.8 \%)$ of the study participants lie in the age group between 29-38 years, and the mean age was 32.6 years with $+/-11.45$ standard deviation. Concerning marital status, $126(41.3 \%)$ of the study participants were single followed by married, 101 (33.1\%). Majority of the study participants were Oromo 184 (60.3\%), followed by Amhara 81 (26.6\%). Concerning educational status, $123(40.3 \%)$ were completed grade 9-12, and 110 (36.1\%) were completed grade 1-8. Regarding monthly income, 81 (26.6 $\%)$ gets monthly income 1501-2000 Ethiopian birrs followed by monthly income 1001-1500 Ethiopian birr which accounts 73 (23.9\%). Regarding occupation, 96 (31.5\%) were private employee followed by farmer, 83 (27.2\%). Majority of the study participants, 202 (66.2 \%) had living companion. (Table 1).

\section{CLINICAL AND BEHAVIORAL CHARACTERISTICS OF PARTICIPANTS}


Majority of the study participants, $212(69.5 \%)$ had no co-morbidity of other chronic diseases. Two hundred-one $(65.9 \%)$ had knowledge about HIV and its treatment. Majority of the study participants, 207 (67.9\%) had disclosed their HIV status to their family. One hundred forty (45.9\%) had CD4 count between 200-500 cells and 111 (36.4\%) had CD4 count between 501-800 cells. Regarding the stage of HIV, 116 $(38.0 \%)$ were on stage II and 98 (32.1\%) were on stage I. One hundred sixty-seven (54.8\%) of the study participants had poor social support and the remaining 138 (45.2\%) had good social support. Majority of the study participants, 180 (59.0\%) don't experienced social stigma and the remaining $125(41.0 \%)$ had experienced social stigma. One hundred ninety-four (63.6\%) of the study participants had no history of current substance use. Concerning the disease duration, 115 (37.7 \%) had duration of 6-10 years, followed by 104 (34.1\%) which was 1-5 years. Regarding the duration of treatment, 116 (38.0\%) had been on the treatment for 1-5 years followed by 112 (36.7\%) which was 6-10 years. Majority of the study participants, 191 (62.6\%) had no adverse drug reaction, and the remaining 114 (37.4\%) had experienced an adverse drug reaction. (Table 2).

\section{LEVEL OF ADHERENCE TO MEDICATION AMONG THE STUDY PARTICIPANTS}

Adherence status was assessed based on the number of pills reported to have been taken one month prior to the data collection period divided by the number of prescribed pills multiplied by $100 \%$. Patients who reported an intake of $\geq 95 \%$ of the prescribed medication were considered adherent; those with a reported intake of $<95 \%$ were classified as non-adherent. Accordingly, out of the total of 305 study participants, $223(73.1 \%)$ were adhered to their medication and $82(26.9 \%)$ were not adhered to their medication (Figure 1).

\section{BIVARIATE LOGISTIC REGRESSION ANALYSIS}

In bivariate analysis, socio-demographic characteristics such as sex, age, marital status, educational status, occupation, income and living companion showed significant association with adherence at Pvalue less than 0.25 . Clinical variables such as HIV stage, side effects of ARV medication, treatment duration, knowledge about HIV and its treatment and comorbidity of other chronic diseases showed significant association with adherence to medication at P-value less than 0.25 . Behavioral variables such as family/social support, substance use, family disclosure status and perceived social stigma showed significant association with adherence at P-value less than 0.25. (Table 3 ).

\section{MULTIVARIATE LOGISTIC REGRESSION ANALYSIS}

In the final model of logistic regression, social/family support, adverse drug reaction, Knowledge about HIV and its treatment, family disclosure status and comorbidity of other chronic diseases were significantly associated with adherence to medication. Study participants who had good family/social support were 7.36 times more likely to adhere to their medication than those who had poor family/social support (AOR=7.36, 95\% Cl: 2.07, 26.10). Study participants who had knowledge about HIV and its treatment were 8.13 times more likely to adhere to their medication than those who had no knowledge about HIV and its treatments (AOR=8.13, 95\% Cl: 3.06, 21.61). Respondents who didn't develop adverse 
drug reactions were 5.62 times more likely to adhere to their medication than those who develop adverse drug reaction (AOR=5.62, 95\% Cl: 2.11, 14.93). Study participants who hadn't other comorbid chronic diseases were 5.46 more likely to adhere to their medication than those who had other comorbid chronic illness (AOR=5.46, 95\% Cl: 1.86, 16.02).

Study participants who disclosed their HIV status to their family were 5.27 times more likely to adhere to their medication than those who don't disclosed their HIV status to their family (AOR=5.27, $95 \% \mathrm{Cl}: 2.20$, 12.62). (Table 4).

\section{Discussion}

This study examined the level of adherence to ART and associated factors among HIV/AIDS patients in Nekemte referral hospital, West Ethiopia. The overall level of adherence to medication among peoples living with HIV/AIDS in this study is $73.1 \%$. This level of adherence is slightly consistent with study done in Southern Ethiopia (68.0\%) [20], Northern Tanzania (71.0\%) [21] and South Africa (69.0\%) [27]. However; it is lower than a study done in China (85.5\%) [22], Eastern Ethiopia (85.0 \%) [23], North-West Ethiopia (88.2 \%) [12], Nepal (87.4\%) [28], Myanmar (84.0\%) [29] and Togo (78.4 \%) [30]. On the other hand, the level of adherence to ARV medication among HIV/AIDS patients in this study is higher than study done in Ghana (62.2\%) [24] and Northern Tanzania (54.9\%) [25]. The difference might be due to variation in sample size, study design and study participant's variation. The level of adherence in this study is lower than world health organization requirement level which is > $95 \%$ [19].

In this study, factors such as social/family support, adverse drug reaction, Knowledge about HIV and its treatment, family disclosure status and comorbidity of other chronic diseases were significantly associated with adherence to ARV medication. Respondents who had no family/social support were found to be non-adherent to medication than those who have family/social support. Support from family and friends have immediate and long-term positive influences on their adherence. This finding is consistent with study done in Ghana [24] and Eastern Ethiopia [23]. However; study done in China [22], Southern Ethiopia [20], South Africa [27], Nepal [28], Myanmar [29], Togo [30] and North West Ethiopia [12] didn't show significant association between family/social support and adherence to antiretroviral medication.

Respondents who developed adverse drug reaction were less adherent to their medication than those who didn't develop adverse drug reaction. Adherence to antiretroviral therapy was negatively affected in HIV/AIDS patients who experienced side effects. This might be due to the fact that study participants might skip their medication to avoid drug side effects. This finding is consistent with a study done in Ghana [24], Nepal [28], South Africa [27] and Cameroon [26]. However; this result is not supported with study done in China [22], Eastern Ethiopia [23], Togo [30], Myanmar [29] and North West Ethiopia [12].

The finding of this study also showed that study participants who had knowledge about HIV and its treatment were more adhered to their medication than those who had no knowledge about HIV and its treatment. This is due to the fact that knowledge on HIV and its treatment might increase their awareness 
and access to HIV therapy which might further increase adherence to medication. This finding is consistent with study done in Gonder, North West Ethiopia [12], but not supported with many other studies $[20,22,23,24,27,28$ and 29].

In this study, study participants who disclosed their HIV status to their families were more adhered to their medication than who didn't disclosed their HIV status. This is similar with study done in China [22], Tanzania [25], Eastern Ethiopia [23], North West Ethiopia [12], South Africa [27], Myanmar [29] and Togo [30]. When there is no self- disclosure about HIV status, the persons may fear to take their treatments and miss the medication. Participants who did not disclose their HIV status put more pressure on themselves in terms of taking regular medication and might skip their medication. On the other hand, non-disclosure might impede the participants from obtaining social support and patients with lower social support might to show poor adherence to their medication.

Respondents who had comorbidity of other chronic illness was less adherent to their medication than those who had no comorbidity of other chronic illness. The possible reason might be that when patients had co-morbidities, they might have pill burden. When a number of pill increases, the patient might experience more adverse effects from the medications which potentially lead them to skip their treatment. This finding is supported with study done in China [22], Cameroon [26], Eastern Ethiopia [23], Southern Ethiopia [20], and North West Ethiopia [12]. However; this finding is not supported with study done in Ghana [24] and Northern Tanzania [21]. Unlike to other studies done in different parts of the world, age, monthly income, marital status, waiting time, number of pills and substance use didn't show significant association with adherence to medication in this study.

\section{LIMITATION OF THE STUDY}

Causality cannot be confirmed since the research design was cross-sectional. Adherence was assessed based on data taken during the previous one month. So, the participants might be subjected to recall bias.

\section{Conclusions}

In this study, the level of adherence to antiretroviral therapy was found low compared to the WHO standard. Social/family support, adverse drug reaction, knowledge about HIV and its treatment, disclosure status and comorbidity of other chronic diseases were significantly associated with adherence. The clinician should emphasize adverse drug reaction, early detect and treat co-morbidities, improve knowledge through health education, and encourage HIV/AIDS patient to disclose their HIV status to improve medication adherence.

\section{Abbreviations}

AIDS: Acquired immunodeficiency syndrome, AOR: Adjusted odd ratio, ART: Anti-retroviral therapy, ARV: Anti-retroviral, Cl: Confidence interval, EFHAPCO: Ethiopian Federal HIV/AIDS Prevention and Control 
Office, HIV: Human immunodeficiency, SPSS: Statistical Package for Social Science, WHO: World Health Organization

\section{Declarations}

\section{Ethical approval and consent to participate}

The study was reviewed and approved by the Institutional Review Boards of Wollega University Ethical review board. The purpose of the study was explained to medical director and staffs of the hospital and permission was obtained. All participants of the study were provided written consent, clearly stating the objectives of the study and their right to refuse. Filled out questionnaires were carefully handled and all access to results was kept strictly within the author.

\section{Consent for publication}

Not applicable

\section{Availability of data and materials}

The data used during this study are available on request.

\section{Competing Interests}

I declare that I have no competing interests.

\section{Funding}

No funding was received for this research work.

\section{Authors' Contributions}

Overall activities of this study (conceptualization of the study, designing, result writing, analyzing the finding and writing and approving the manuscript) were carried out by the author MA.

\section{Acknowledgment}

I would like to acknowledge Nekemte referral hospital medical director and staffs for their cooperation. I am also grateful to the study participants who voluntarily agreed to be interviewed and participated in the study.

\section{References}

1. WHO. HIV/AIDS and mental health. Geneva: Switzerland; 2008.

2. WHO, HIV/AIDS (Internet). WHO. http://www. who.int/gho/hiv/en/. Accessed 23 Feb 2017. 
3. U. Nation, United Nations Political Declaration on Ending AIDS: 2020 Global Prevention Targets and Commitments, 2016.

4. UNAIDS. GLOBAL AIDS UPDATE. 2016. http://www.unaids.org/en/resources/ documents/2016/Global-AIDS-update-2016.

5. ART failure and strategies for switching ART regimens, Report of the WHO expert consultation Copenhagen, 7 December 2007.

6. Jean B, Nachega MH, Dowdy DW, Chaisson RE, Regensberg L, Maartens G. Adherence to nonnucleoside reverse transcriptase inhibitor-based HIV therapy and Virologic outcomes. Ann Intern Med. 2007;146:564-73.

7. Jean B, Nachega MH, Nguyen H, Dowdy DW, Chaisson RE, Regensberg L, Cotton M, Maartens G. Antiretroviral therapy adherence, Virologic and immunologic outcomes in adolescents compared with adults in southern Africa. J Acquir Immune Defic Syndr. 2009;51(1):65-71.

8. David L, Paterson M, BS, FRACP, Swindells S, Mohr J, MSW, Brester M, RN, Emanuel N, Vergis, MMW CS, Singh N. Adherence to protease inhibitor therapy and outcomes in patients with HIV infection. Ann Intern Med. 2000; 133(1):21-30.

9. Sharon Mannheimer GF, Matts J, Child C, Chesney M. The consistency of adherence to antiretroviral therapy predicts biologic outcomes for human immunodeficiency virus-infected persons in clinical trials. Clin Infect Dis. 2002;34(8):1115-21.

10. Howard AAA, Julia H, Lo Y, Vlahov D, Rich JD, Schuman P, Stone VE, Smith DK, Schoenbaum EE. A prospective study of adherence and viral load in a large multi-center cohort of HIV-infected women. International AIDS society. 2002;16(16):2175-82.

11. Edward L. Machtinger DRB. Adherence to HIV antiretroviral therapy. University of California san Francisco: HIV InSite Knowledge Base chapter; 2006.

12. Molla et al. Adherence to antiretroviral therapy and associated factors among HIV positive adults attending care and treatment in University of Gondar Referral Hospital, Northwest Ethiopia. BMC Infectious Diseases (2018) 18:266 https://doi.org/10.1186/s12879-018-3176-8

13. Li JZ, SG HR, Heiseya A, Bangsbergd DR, Kuritzkesa DR. Incomplete adherence to antiretroviral therapy is associated with higher levels of residual HIV-1 viremia. AIDS. 2014;28(2):181-6.

14. ID JAGS, de Brito AM, da Silva CAL. Factors associated with non-adherence to antiretroviral therapy in adults with AIDS in the first six months of treatment in Salvador, Bahia state, Brazil. Cad Saúde Pública, Rio de Janeiro. 2015;31(6):1-11.

15. Hogan D, Salomon J (2005) Prevention and treatment of HIV/AIDS in resource limited settings. Bulletin of WHOM 83: 2.

16. Paterson DL, Swindells S, Mohr J, Brester M, Vergis EN, Squier C, Wagener MM, Singh N. Adherence to protease inhibitor therapy and outcomes in patients with HIV infection. Ann Intern Med. 2000; 133(1):21-30.

17. Sahay S, Reddy KS, Dhayarkar S. Optimizing adherence to antiretroviral therapy. Indian J Med Res. 2011; 134(6):835. 
18. Tefera G. Personal factors influencing patients ART adherence in Addis Ababa, Ethiopia. J Assoc Nurses AIDS Care. 2011; 24(6):530-8.

19. World Health Organization, Adherence to Long-Term Therapies Evidence for Action World Health Organization; 2013; XII: 92-106.

20. Koyra HC (2018) Adherence to Antiretroviral Therapy among Adult Persons Living with HIV/ AIDS in Southern Ethiopia. Int J Virol AIDS 5:038. doi.org/10.23937/2469-567X/1510038

21. Semvua SK,Orrell C, MmbagaBT, Semvua HH, Bartlett JA, Boulle AA (2017) Predictors of nonadherence to antiretroviral therapy among HIV infected patients in northern Tanzania. PLoS ONE 12(12): e0189460.https://doi. org/10.1371/journal.pone.0189460

22. Yu et al. Medication adherence to antiretroviral therapy among newly treated people living with HIV. BMC Public Health (2018) 18:825 https://doi.org/10.1186/s12889-018-5731-z

23. Letta et al. Factors associated with adherence to Antiretroviral Therapy (ART) among adult people living with HIV and attending their clinical care, Eastern Ethiopia. BMC International Health and Human Rights (2015) 15:33

24. Obirikorang et al. Predictors of Adherence to Antiretroviral Therapy among HIV/AIDS Patients in the Upper West Region of Ghana. Hindawi Publishing Corporation ISRNAIDS Volume 2013, Article ID 873939,7pages http://dx.doi.org/10.1155/2013/873939

25. Kahema SE, Mgabo MR, Emidi B, Sigalla GN, Kajeguka DC (2018) Factors Influencing Adherence to Antiretroviral Therapy among HIV Infected Patients in Nyamagana-Mwanza, Northern Tanzania: A Cross Sectional Study. Int Arch Med Microbiol 1:002.

26. Fonsah JY, NjamnshiAK, Kouanfack C, Qiu F, Njamnshi DM,Tagny CT, et al. (2017) Adherence to Antiretroviral Therapy (ART) in Yaounde '-Cameroon: Association with Opportunistic Infections, Depression, ART Regimen and Side Effects. PLoS ONE 12(1): e0170893.doi:

10.1371/journal.pone. 0170893

27. Adeniyi et al. Factors affecting adherence to antiretroviral therapy among pregnant women in the Eastern Cape, South Africa. BMC Infectious Diseases (2018) 18:175 https://doi.org/10.1186/s12879018-3087-8

28. Neupane et al. Adherence to antiretroviral treatment and associated factors among people living with HIV and AIDS in CHITWAN, Nepal. BMC Public Health (2019) 19:720 https://doi.org/10.1186/s12889-019-7051-3

29. Aye et al. Non-adherence to anti-retroviral therapy among HIV infected adults in Mon State of Myanmar. BMC Public Health (2017) 17:391 DOI 10.1186/s12889-017-4309-5

30. Yaya et al. Predictors of adherence to antiretroviral therapy among people living with HIV and AIDS at the regional hospital of Sokode, Togo. BMC Public Health 2014, 14:1308 http://www.biomedcentral.com/1471-2458/14/1308

\section{Tables}


Table 1: Distribution of study participants by socio-demographic characteristics among HIV/AIDS patients at Nekemte referral hospital, West Ethiopia, 2019 ( $\mathrm{n}=305)$

\begin{tabular}{|c|c|c|c|}
\hline \multicolumn{2}{|l|}{ Variables } & Frequency & Percentage \\
\hline \multirow[t]{3}{*}{ Sex } & Male & 140 & 45.9 \\
\hline & Female & 165 & 54.1 \\
\hline & Total & 305 & 100 \\
\hline \multirow[t]{6}{*}{ Ethnicity } & Oromo & 184 & 60.3 \\
\hline & Amhara & 81 & 26.6 \\
\hline & Tigre & 18 & 5.9 \\
\hline & Gurage & 12 & 3.9 \\
\hline & Others & 10 & 3.3 \\
\hline & Total & 305 & 100 \\
\hline \multirow[t]{6}{*}{ Age } & $18-28$ & 104 & 34.1 \\
\hline & $29-38$ & 106 & 34.8 \\
\hline & $39-48$ & 46 & 15.1 \\
\hline & $>=48$ & 49 & 16.1 \\
\hline & Total & 305 & 100 \\
\hline & Married & 101 & 33.1 \\
\hline \multirow[t]{4}{*}{ Marital status } & Single & 126 & 41.3 \\
\hline & Divorced & 40 & 13.1 \\
\hline & Widowed & 38 & 12.5 \\
\hline & Total & 305 & 100 \\
\hline \multirow[t]{5}{*}{ Educational status } & No formal education & 20 & 6.6 \\
\hline & Primary school (1-8) & 110 & 36.1 \\
\hline & Secondary (9-12) & 123 & 40.3 \\
\hline & Degree and above & 52 & 17.0 \\
\hline & Total & 305 & 100 \\
\hline \multirow[t]{7}{*}{ Occupational status } & Gov'nt employee & 35 & 11.5 \\
\hline & Private employee & 96 & 31.5 \\
\hline & Farmer & 83 & 27.2 \\
\hline & Merchant & 81 & 26.6 \\
\hline & Others & 10 & 3.3 \\
\hline & Total & 305 & 100 \\
\hline & $<500$ & 62 & 20.3 \\
\hline \multirow[t]{5}{*}{ Monthly income } & $500-1000$ & 56 & 18.4 \\
\hline & $1001-1500$ & 73 & 23.9 \\
\hline & $1501-2000$ & 81 & 26.6 \\
\hline & $>200$ & 33 & 10.8 \\
\hline & Total & 305 & 100 \\
\hline \multirow[t]{3}{*}{ Living companion } & Yes & 202 & 66.2 \\
\hline & No & 103 & 33.8 \\
\hline & Total & 305 & 100 \\
\hline
\end{tabular}

Table 2: Distribution of study participants by clinical and behavioral variables among HIV/AIDS patients at Nekemte referral hospital, West Ethiopia, 2019 ( $n=305)$ 


\begin{tabular}{|c|c|c|c|}
\hline \multicolumn{2}{|l|}{ Variables } & Frequency & Percentage \\
\hline \multirow[t]{5}{*}{ CD4 cell count } & $<200$ & 42 & 13.8 \\
\hline & $200-500$ & 140 & 45.9 \\
\hline & $501-800$ & 111 & 36.4 \\
\hline & $>800$ & 12 & 3.9 \\
\hline & Total & 305 & 100 \\
\hline \multirow[t]{5}{*}{ Stage of HIV } & Stage I & 98 & 32.1 \\
\hline & Stage II & 116 & 38.0 \\
\hline & Stage III & 48 & 15.7 \\
\hline & Stage IV & 43 & 14.1 \\
\hline & Total & 305 & 100 \\
\hline \multirow[t]{3}{*}{ Social support } & Good & 138 & 45.2 \\
\hline & Poor & 167 & 54.8 \\
\hline & Total & 305 & 100 \\
\hline \multirow[t]{3}{*}{ Perceived social stigma } & Yes & 125 & 41.0 \\
\hline & No & 180 & 59.0 \\
\hline & Total & 305 & 100 \\
\hline \multirow[t]{3}{*}{ Current substance use } & Yes & 111 & 36.4 \\
\hline & No & 194 & 63.6 \\
\hline & Total & 305 & 100 \\
\hline \multirow[t]{5}{*}{ Duration of disease } & $<1$ year & 47 & 15.4 \\
\hline & 1-5 years & 104 & 34.1 \\
\hline & $5-10$ years & 115 & 37.7 \\
\hline & >10 years & 39 & 12.8 \\
\hline & Total & 305 & 100 \\
\hline \multirow[t]{3}{*}{ Adverse drug reaction } & Yes & 114 & 37.4 \\
\hline & No & 191 & 62.6 \\
\hline & Total & 305 & 100 \\
\hline \multirow[t]{3}{*}{ Waiting time } & $<30$ minutes & 186 & 61.0 \\
\hline & $>/=30$ minutes & 119 & 39.0 \\
\hline & Total & 305 & 100 \\
\hline \multirow[t]{2}{*}{ Family disclosure status } & Yes & 207 & 67.9 \\
\hline & No & 98 & 32.1 \\
\hline \multirow[t]{2}{*}{ Comorbidity of other chronic diseases } & Total & 305 & 100 \\
\hline & Yes & 93 & 30.5 \\
\hline \multirow[t]{5}{*}{ Knowledge about HIV and its treatment } & No & 212 & 69.5 \\
\hline & Total & 305 & 100 \\
\hline & Yes & 201 & 65.9 \\
\hline & No & 104 & 34.1 \\
\hline & Total & 305 & 100 \\
\hline
\end{tabular}

Table 3: Bivariate logistic regression analysis of factors associated with adherence among HIV/AIDS patients at Nekemte referral hospital, West Ethiopia, 2019 ( $\mathrm{n}=305)$ 


\begin{tabular}{|c|c|c|c|c|}
\hline \multirow[b]{2}{*}{ Variables } & \multicolumn{2}{|c|}{ Adherence } & \multirow[b]{2}{*}{$\begin{array}{l}\text { COR (95\%) } \\
\text { CI }\end{array}$} & \multirow[b]{2}{*}{$\begin{array}{l}\mathrm{P} \\
\text { value }\end{array}$} \\
\hline & Adhered (\%) & $\begin{array}{l}\text { Not adhered } \\
\text { (\%) }\end{array}$ & & \\
\hline \multicolumn{5}{|l|}{ Sex } \\
\hline Male & $97(69.3 \%)$ & $43(30.7 \%)$ & 1 & \\
\hline Female & $126(76.4 \%)$ & $39(23.6 \%)$ & $0.69(0.42,1.16)$ & $0.16 *$ \\
\hline \multicolumn{5}{|l|}{ Age (years) } \\
\hline $18-28$ & $69(66.3 \%)$ & $35(33.7 \%)$ & $2.25(0.98,5.16)$ & $0.05 *$ \\
\hline $29-38$ & $78(73.6 \%)$ & $28(26.4 \%)$ & $1.59(0.68,3.70)$ & 0.27 \\
\hline $39-48$ & $36(78.3 \%)$ & $10(21.7 \%)$ & $1.23(0.45,3.37)$ & 0.68 \\
\hline$>48$ & $40(81.6 \%)$ & $9(18.4 \%)$ & 1 & \\
\hline \multicolumn{5}{|l|}{ Marital status } \\
\hline Married & $81(80.2 \%)$ & $20(19.8 \%)$ & 1 & \\
\hline Single & $92(73.0 \%)$ & $34(27.0 \%)$ & $1.49(0.79,2.80)$ & $0.20 *$ \\
\hline Divorced & $26(65.0 \%)$ & $14(35.0 \%)$ & $2.18(0.96,4.91)$ & $0.06 *$ \\
\hline Widowed & $24(63.2 \%)$ & $14(36.8 \%)$ & $2.36(1.04,5.36)$ & $0.04 *$ \\
\hline \multicolumn{5}{|l|}{ Ethnicity } \\
\hline Oromo & $134(72.8 \%)$ & $50(27.2 \%)$ & 1 & \\
\hline Amhara & $61(75.3 \%)$ & $20(24.7 \%)$ & $0.87(0.48,1.60)$ & 0.67 \\
\hline Tigre & $13(72.2 \%)$ & $5(27.8 \%)$ & $1.03(0.35,3.03)$ & 0.95 \\
\hline Gurage & $9(75.0 \%)$ & $3(25.0 \%)$ & $0.89(0.23,3.43)$ & 0.87 \\
\hline Others & $6(60.0 \%)$ & $4(40.0 \%)$ & $1.78(0.48,6.59)$ & 0.38 \\
\hline \multicolumn{5}{|l|}{ Educational status } \\
\hline No formal education & $11(55.0 \%)$ & $9(45.0 \%)$ & $2.45(0.83,7.24)$ & $0.10 *$ \\
\hline Primary school (1-8) & $73(66.4 \%)$ & $37(33.6 \%)$ & $1.52(0.72,3.19)$ & 0.26 \\
\hline Secondary school (9-12) & $100(81.3 \%)$ & $23(18.7 \%)$ & $0.69(0.31,1.49)$ & 0.34 \\
\hline College and above & $39(75.0 \%)$ & $13(25.0 \%)$ & 1 & \\
\hline \multicolumn{5}{|l|}{ Residence } \\
\hline Urban & $62(68.9 \%)$ & $28(31.1 \%)$ & $1.34(0.78,2.31)$ & 0.28 \\
\hline Rural & $161(74.9 \%)$ & $54(25.1 \%)$ & 1 & \\
\hline \multicolumn{5}{|l|}{ Occupation } \\
\hline Government employee & $28(80.0 \%)$ & $7(20.0 \%)$ & 1 & \\
\hline Private employee & $72(75.0 \%)$ & $24(25.0 \%)$ & $1.33(0.51,3.44)$ & 0.55 \\
\hline Farmer & $56(67.5 \%)$ & $27(32.5 \%)$ & $1.92(0.74,4.97)$ & $0.17 *$ \\
\hline Merchant & $58(71.6 \%)$ & $23(28.4 \%)$ & $1.58(0.60,4.13)$ & 0.34 \\
\hline Others & $9(90.0 \%)$ & $1(10.0 \%)$ & $0.44(0.04,4.11)$ & 0.47 \\
\hline \multicolumn{5}{|l|}{ Income } \\
\hline$<500 \mathrm{~EB}$ & $35(56.5 \%)$ & $27(43.5 \%)$ & $\begin{array}{l}4.32(1.47 \\
12.66)\end{array}$ & $0.008 *$ \\
\hline 500-1000 EB & $41(73.2 \%)$ & $15(26.8 \%)$ & $2.04(0.66,6.26)$ & $0.21 *$ \\
\hline 1001-1500 EB & $51(69.9 \%)$ & $22(30.1 \%)$ & $2.41(0.82,7.07)$ & $0.10 *$ \\
\hline 1501-2000 EB & $68(84.0 \%)$ & $13(16.0 \%)$ & $1.07(0.34,3.28)$ & 0.90 \\
\hline$>2000 \mathrm{~EB}$ & $28(84.8 \%)$ & $5(15.2 \%)$ & 1 & \\
\hline \multicolumn{5}{|l|}{$\begin{array}{l}\text { Number of pills taken in a } \\
\text { day }\end{array}$} \\
\hline 2 tablets & $114(75.5 \%)$ & $37(24.5 \%)$ & 1 & \\
\hline 3 tablets & $52(72.2 \%)$ & $20(27.8 \%)$ & $1.18(0.62,2.23)$ & 0.60 \\
\hline 4 tablets & $43(69.4 \%)$ & $19(30.6 \%)$ & $1.36(0.70,2.62)$ & 0.35 \\
\hline
\end{tabular}




\begin{tabular}{|c|c|c|c|c|}
\hline Living companion & & & & \\
\hline Yes & $178(88.1 \%)$ & $24(11.9 \%)$ & 1 & \\
\hline No & $45(43.7 \%)$ & $58(56.3 \%)$ & $9.55(5.36,17.0)$ & $0.000 *$ \\
\hline \multicolumn{5}{|l|}{ CD4 cell } \\
\hline$<200$ & 31 (73.8 \%) & $11(26.2 \%)$ & $0.71(0.17,2.83)$ & 0.62 \\
\hline $200-500$ & $100(71.4 \%)$ & $40(28.6 \%)$ & $0.80(0.22,2.80)$ & 0.72 \\
\hline $501-800$ & $84(75.7 \%)$ & $27(24.3 \%)$ & $0.64(0.17,2.3)$ & 0.49 \\
\hline$>800$ & $8(66.7 \%)$ & $4(33.3 \%)$ & 1 & \\
\hline \multicolumn{5}{|l|}{ HIV stage } \\
\hline Stage I & $73(74.5 \%)$ & $25(25.5 \%)$ & 1 & \\
\hline Stage II & $88(75.9 \%)$ & $28(24.1 \%)$ & $0.92(0.49,1.73)$ & 0.81 \\
\hline Stage III & $31(64.6 \%)$ & $17(35.4 \%)$ & $1.60(0.76,3.37)$ & $0.21 *$ \\
\hline Stage IV & $31(72.1 \%)$ & $12(27.9 \%)$ & $1.13(0.50,2.53)$ & 0.76 \\
\hline \multicolumn{5}{|c|}{ Side effect of ARV drugs } \\
\hline Yes & $44(38.6 \%)$ & $70(61.4 \%)$ & $23.7(11.83,47.57)$ & $0.000 *$ \\
\hline No & $179(93.7 \%)$ & $12(6.3 \%)$ & 1 & \\
\hline \multicolumn{5}{|l|}{ Family/social support } \\
\hline Good & $134(97.1 \%)$ & $4(2.9 \%)$ & 1 & \\
\hline Poor & $89(53.3 \%)$ & $78(46.7 \%)$ & $19.36(10.37,33.05)$ & $0.000 *$ \\
\hline \multicolumn{5}{|l|}{ Perceived stigma } \\
\hline Yes & $59(47.2 \%)$ & $66(52.8 \%)$ & $11.46(6.15,21.35)$ & $0.000 *$ \\
\hline No & $164(91.1 \%)$ & $16(8.9 \%)$ & 1 & \\
\hline \multicolumn{5}{|l|}{ Substance use } \\
\hline Yes & $46(41.4 \%)$ & $65(58.6 \%)$ & $14.71(7.87,27.47)$ & $0.000 *$ \\
\hline No & $177(91.2 \%)$ & $17(8.8 \%)$ & 1 & \\
\hline \multicolumn{5}{|l|}{ Disease duration } \\
\hline$<1$ year & $35(74.5 \%)$ & $12(25.5 \%)$ & $1.14(0.42,3.08)$ & 0.79 \\
\hline $1-5$ years & $76(73.1 \%)$ & $28(26.9 \%)$ & $1.22(0.51,2.90)$ & 0.64 \\
\hline $6-10$ years & $82(71.3 \%)$ & $33(28.7 \%)$ & $1.34(0.57,3.13)$ & 0.49 \\
\hline$>10$ years & $30(76.9 \%)$ & $9(23.1 \%)$ & 1 & \\
\hline \multicolumn{5}{|l|}{ Treatment duration } \\
\hline$<1$ year & $38(79.2 \%)$ & $10(20.8 \%)$ & 1 & \\
\hline $1-5$ years & $85(73.3 \%)$ & $31(26.7 \%)$ & $1.38(0.61,3.11)$ & 0.42 \\
\hline $6-10$ years & $78(69.6 \%)$ & $34(30.4 \%)$ & $1.65(0.74,3.70)$ & $0.21 *$ \\
\hline$>10$ years & $22(75.9 \%)$ & $7(24.1 \%)$ & $1.20(0.40,3.63)$ & 0.73 \\
\hline \multicolumn{5}{|c|}{ Knowledge about HIV and its treatment } \\
\hline Knowledgeable & $181(90.0 \%)$ & $20(10.0 \%)$ & 1 & \\
\hline Not knowledgeable & $42(40.4 \%)$ & $62(59.6 \%)$ & $13.36(7.29,24.47)$ & $0.000 *$ \\
\hline \multicolumn{5}{|l|}{ Waiting time } \\
\hline$<30$ minutes & $140(75.3 \%)$ & $46(24.7 \%)$ & 1 & \\
\hline$>/=30$ minutes & $83(69.7 \%)$ & $36(30.3 \%)$ & $1.32(0.79,2.20)$ & 0.28 \\
\hline \multicolumn{5}{|c|}{ comorbidity of other chronic illness } \\
\hline Yes & $35(37.6 \%)$ & $58(62.4 \%)$ & $12.98(7.14,23.58)$ & $0.000 *$ \\
\hline No & $188(88.7 \%)$ & $24(11.3 \%)$ & 1 & \\
\hline \multicolumn{5}{|c|}{ Family disclosure status } \\
\hline Yes & $184(88.9 \%)$ & $23(11.1 \%)$ & 1 & \\
\hline No & $39(39.8 \%)$ & $59(60.2 \%)$ & $12.10(6.68,21.89)$ & $0.000 *$ \\
\hline
\end{tabular}


Notes * shows significant at $P$-value $<0.25$

Table 4: Multivariate logistic regression analysis of factors associated with adherence among HIV/AIDS patients at Nekemte referral hospital, West Ethiopia, $2019(n=305)$. 


\begin{tabular}{|c|c|c|c|c|c|c|}
\hline \multirow[b]{2}{*}{ Variables } & \multicolumn{2}{|c|}{ Adherence } & \multirow[b]{2}{*}{$\begin{array}{c}\text { COR } \\
(95 \%) \mathrm{CI}\end{array}$} & \multirow[b]{2}{*}{$\begin{array}{l}P \\
\text { value }\end{array}$} & \multirow[b]{2}{*}{ AOR (95\%) CI } & \multirow[b]{2}{*}{$\begin{array}{l}\mathrm{P} \\
\text { value }\end{array}$} \\
\hline & $\begin{array}{l}\text { Adhered } \\
\text { (\%) }\end{array}$ & $\begin{array}{l}\text { Not adhered } \\
\text { (\%) }\end{array}$ & & & & \\
\hline \multicolumn{7}{|l|}{ Sex } \\
\hline Male & $97(69.3 \%)$ & $43(30.7 \%)$ & 1 & & 1 & \\
\hline Female & $126(76.4 \%)$ & 39 (23.6 \%) & $\begin{array}{l}0.69(0.42, \\
1.16)\end{array}$ & 0.16 & $\begin{array}{l}0.53(0.22, \\
1.29)\end{array}$ & 0.17 \\
\hline \multicolumn{7}{|l|}{ Age (years) } \\
\hline $18-28$ & $69(66.3 \%)$ & 35 (33.7 \%) & $\begin{array}{l}2.25(0.98, \\
5.16)\end{array}$ & 0.05 & $\begin{array}{l}2.65(0.32, \\
21.4)\end{array}$ & 0.36 \\
\hline $29-38$ & 78 (73.6 \%) & 28 (26.4 \%) & $\begin{array}{l}1.59(0.68, \\
3.70) \\
\end{array}$ & 0.27 & $\begin{array}{l}1.63(0.19, \\
13.4)\end{array}$ & 0.64 \\
\hline $39-48$ & 36 (78.3 \%) & $10(21.7 \%)$ & $\begin{array}{l}1.23(0.45, \\
3.37)\end{array}$ & 0.68 & $\begin{array}{l}2.38(0.14, \\
29.6)\end{array}$ & 0.54 \\
\hline$>48$ & $40(81.6 \%)$ & $9(18.4 \%)$ & 1 & & 1 & \\
\hline \multicolumn{7}{|l|}{ Marital status } \\
\hline Married & $81(80.2 \%)$ & $20(19.8 \%)$ & 1 & & 1 & \\
\hline Single & $92(73.0 \%)$ & $34(27.0 \%)$ & $\begin{array}{l}1.49(0.79, \\
2.80)\end{array}$ & 0.20 & $\begin{array}{l}2.29(0.72, \\
7.26)\end{array}$ & 0.15 \\
\hline Divorced & $26(65.0 \%)$ & $14(35.0 \%)$ & $\begin{array}{l}2.18(0.96 \\
4.91) \\
\end{array}$ & 0.06 & $\begin{array}{l}4.87(0.96 \\
24.62) \\
\end{array}$ & 0.06 \\
\hline Widowed & $24(63.2 \%)$ & $14(36.8 \%)$ & $\begin{array}{l}2.36(1.04, \\
5.36)\end{array}$ & 0.04 & $\begin{array}{l}2.35(0.47, \\
11.63)\end{array}$ & 0.29 \\
\hline \multicolumn{7}{|l|}{ Ethnicity } \\
\hline Oromo & $134(72.8 \%)$ & $50(27.2 \%)$ & 1 & & 1 & \\
\hline Amhara & $61(75.3 \%)$ & $20(24.7 \%)$ & $\begin{array}{l}0.87(0.48, \\
1.60)\end{array}$ & 0.67 & $\begin{array}{l}0.28(0.09, \\
0.83)\end{array}$ & 0.22 \\
\hline Tigre & $13(72.2 \%)$ & $5(27.8 \%)$ & $\begin{array}{l}1.03(0.35, \\
3.03)\end{array}$ & 0.95 & $\begin{array}{l}1.08(0.12, \\
9.64)\end{array}$ & 0.94 \\
\hline Gurage & $9(75.0 \%)$ & $3(25.0 \%)$ & $\begin{array}{l}0.89(0.23, \\
3.43) \\
\end{array}$ & 0.87 & $\begin{array}{l}0.69(0.09, \\
5.29) \\
\end{array}$ & 0.72 \\
\hline Others & $6(60.0 \%)$ & $4(40.0 \%)$ & $\begin{array}{l}1.78(0.48, \\
6.59)\end{array}$ & 0.38 & $\begin{array}{l}0.88(0.10, \\
7.35)\end{array}$ & 0.91 \\
\hline \multicolumn{7}{|l|}{ Educational status } \\
\hline No formal education & 11 (55.0\%) & $9(45.0 \%)$ & $\begin{array}{l}2.45(0.83, \\
7.24)\end{array}$ & 0.10 & $\begin{array}{l}4.74(0.54, \\
41.32)\end{array}$ & 0.15 \\
\hline Primary school (1-8) & 73 (66.4\%) & 37 (33.6 \%) & $\begin{array}{l}1.52(0.72, \\
3.19) \\
\end{array}$ & 0.26 & $\begin{array}{l}1.72(0.45, \\
6.57) \\
\end{array}$ & 0.42 \\
\hline $\begin{array}{l}\text { Secondary school (9- } \\
\text { 12) }\end{array}$ & $100(81.3 \%)$ & $23(18.7 \%)$ & $\begin{array}{l}0.69(0.31 \\
1.49) \\
\end{array}$ & 0.34 & $\begin{array}{l}0.88(0.23, \\
3.30) \\
\end{array}$ & 0.86 \\
\hline College and above & $39(75.0 \%)$ & $13(25.0 \%)$ & 1 & & 1 & \\
\hline \multicolumn{7}{|l|}{ Residence } \\
\hline Urban & $62(68.9 \%)$ & 28 (31.1\%) & $\begin{array}{l}1.34(0.78 \\
2.31) \\
\end{array}$ & 0.28 & $\begin{array}{l}1.42(0.50, \\
4.02) \\
\end{array}$ & 0.50 \\
\hline Rural & $161(74.9 \%)$ & $54(25.1 \%)$ & 1 & & 1 & \\
\hline \multicolumn{7}{|l|}{ Occupation } \\
\hline Government employee & $28(80.0 \%)$ & $7(20.0 \%)$ & 1 & & 1 & \\
\hline Private employee & $72(75.0 \%)$ & $24(25.0 \%)$ & $\begin{array}{l}1.33(0.51, \\
3.44)\end{array}$ & 0.55 & $\begin{array}{l}0.80(0.12, \\
5.16)\end{array}$ & 0.82 \\
\hline
\end{tabular}




\begin{tabular}{|c|c|c|c|c|c|c|}
\hline Farmer & 56 (67.5 \%) & 27 (32.5 \%) & $\begin{array}{l}1.92(0.74 \\
4.97)\end{array}$ & 0.17 & $\begin{array}{l}2.96(0.43, \\
20.35)\end{array}$ & 0.26 \\
\hline Merchant & $58(71.6 \%)$ & $23(28.4 \%)$ & $\begin{array}{l}1.58(0.60 \\
4.13)\end{array}$ & 0.34 & $\begin{array}{l}2.14(0.35 \\
12.8)\end{array}$ & 0.40 \\
\hline Others & 9 (90.0 \%) & $1(10.0 \%)$ & $\begin{array}{l}0.44(0.04 \\
4.11)\end{array}$ & 0.47 & $\begin{array}{l}0.03(0.001, \\
3.14)\end{array}$ & 0.62 \\
\hline \multicolumn{7}{|l|}{ Income } \\
\hline$<500$ EB & 35 (56.5 \%) & 27 (43.5\%) & $\begin{array}{l}4.32(1.47 \\
12.66)\end{array}$ & 0.008 & $\begin{array}{l}1.98(0.19, \\
20.8)\end{array}$ & 0.56 \\
\hline 500-1000 EB & 41 (73.2 \%) & 15 (26.8 \%) & $\begin{array}{l}.04(0.66, \\
6.26) \\
\end{array}$ & 0.21 & $\begin{array}{l}0.69(0.06, \\
7.48)\end{array}$ & 0.76 \\
\hline 1001-1500 EB & 51 (69.9\%) & 22 (30.1\%) & $\begin{array}{l}2.41(0.82 \\
7.07)\end{array}$ & 0.10 & $\begin{array}{l}1.72(0.17 \\
16.8)\end{array}$ & 0.64 \\
\hline 1501-2000 ЕВ & $68(84.0 \%)$ & $13(16.0 \%)$ & $\begin{array}{l}1.07(0.34 \\
3.28)\end{array}$ & 0.90 & $\begin{array}{l}1.18(0.09 \\
15.31)\end{array}$ & 0.89 \\
\hline$>2000 \mathrm{~EB}$ & $28(84.8 \%)$ & $5(15.2 \%)$ & 1 & & 1 & \\
\hline \multicolumn{7}{|c|}{$\begin{array}{l}\text { Number of pills taken } \\
\text { in a day }\end{array}$} \\
\hline 2 tablets & $114(75.5 \%)$ & $37(24.5 \%)$ & 1 & & 1 & \\
\hline 3 tablets & $52(72.2 \%)$ & $20(27.8 \%)$ & $\begin{array}{l}1.18(0.62, \\
2.23) \\
\end{array}$ & 0.60 & $\begin{array}{l}2.19(0.71, \\
6.71)\end{array}$ & 0.16 \\
\hline 4 tablets & 43 (69.4 \%) & 19 (30.6 \%) & $\begin{array}{l}.36(0.70, \\
2.62) \\
\end{array}$ & 0.35 & $\begin{array}{l}3.24(0.94, \\
11.1)\end{array}$ & 0.61 \\
\hline$>4$ tablets & $14(70.0 \%)$ & $6(30.0 \%)$ & $\begin{array}{l}1.32(0.47 \\
3.68)\end{array}$ & 0.59 & $\begin{array}{l}0.91(0.10 \\
8.26)\end{array}$ & 0.93 \\
\hline
\end{tabular}




\begin{tabular}{|c|c|c|c|c|c|c|}
\hline \multicolumn{7}{|c|}{ Living companion } \\
\hline Yes & $\begin{array}{l}178(88.1 \\
\%)\end{array}$ & $\begin{array}{l}24(11.9 \\
\%)\end{array}$ & 1 & & 1 & \\
\hline No & $\begin{array}{l}45(43.7 \\
\%)\end{array}$ & $\begin{array}{l}58(56.3 \\
\%)\end{array}$ & $9.55(5.36,17.0)$ & 0.000 & $\begin{array}{l}0.48(0.04, \\
5.16)\end{array}$ & 0.54 \\
\hline \multicolumn{7}{|l|}{ CD4 cell } \\
\hline$<200$ & $\begin{array}{l}31(73.8 \\
\%)\end{array}$ & $\begin{array}{l}11(26.2 \\
\%)\end{array}$ & $0.71(0.17,2.83)$ & 0.62 & $\begin{array}{l}2.38(0.22, \\
25.15)\end{array}$ & 0.46 \\
\hline $200-500$ & $\begin{array}{l}100(71.4 \\
\%)\end{array}$ & $\begin{array}{l}40(28.6 \\
\%)\end{array}$ & $0.80(0.22,2.80)$ & 0.72 & $\begin{array}{l}1.05(0.12, \\
8.7)\end{array}$ & 0.95 \\
\hline $501-800$ & $\begin{array}{l}84(75.7 \\
\%)\end{array}$ & $\begin{array}{l}27(24.3 \\
\%)\end{array}$ & $0.64(0.17,2.3)$ & 0.49 & $\begin{array}{l}0.98(0.11, \\
8.32)\end{array}$ & 0.98 \\
\hline$>800$ & $8(66.7 \%)$ & $\begin{array}{l}4(33.3 \\
\%)\end{array}$ & 1 & & 1 & \\
\hline \multicolumn{7}{|l|}{ HIV stage } \\
\hline Stage I & $\begin{array}{l}73(74.5 \\
\%)\end{array}$ & $\begin{array}{l}25(25.5 \\
\%)\end{array}$ & 1 & & 1 & \\
\hline Stage II & $\begin{array}{l}88(75.9 \\
\%)\end{array}$ & $\begin{array}{l}28(24.1 \\
\%)\end{array}$ & $0.92(0.49,1.73)$ & 0.81 & $\begin{array}{l}2.36(0.63, \\
8.80)\end{array}$ & 0.19 \\
\hline Stage III & $\begin{array}{l}31(64.6 \\
\%)\end{array}$ & $\begin{array}{l}17(35.4 \\
\%)\end{array}$ & $1.60(0.76,3.37)$ & 0.21 & $\begin{array}{l}1.11(0.17, \\
6.88)\end{array}$ & 0.91 \\
\hline Stage IV & $\begin{array}{l}31(72.1 \\
\%)\end{array}$ & $\begin{array}{l}12(27.9 \\
\%)\end{array}$ & $1.13(0.50,2.53)$ & 0.76 & $\begin{array}{l}1.32(0.22, \\
7.86)\end{array}$ & 0.75 \\
\hline \multicolumn{7}{|c|}{ Family/social support } \\
\hline Good & $\begin{array}{l}134(97.1 \\
\%)\end{array}$ & $4(2.9 \%)$ & 1 & & 1 & \\
\hline Poor & $\begin{array}{l}89(53.3 \\
\%)\end{array}$ & $\begin{array}{l}78(46.7 \\
\%)\end{array}$ & $\begin{array}{l}19.36(10.37, \\
33.05)\end{array}$ & 0.000 & $\begin{array}{l}7.36(2.07, \\
26.10)\end{array}$ & $0.002 *$ \\
\hline \multicolumn{7}{|c|}{ Perceived stigma } \\
\hline Yes & $\begin{array}{l}59(47.2 \\
\%) \\
\end{array}$ & $\begin{array}{l}66(52.8 \\
\%)\end{array}$ & $\begin{array}{l}11.46 \text { (6.15, } \\
21.35)\end{array}$ & 0.000 & $\begin{array}{l}1.50(0.36, \\
6.15)\end{array}$ & 0.57 \\
\hline No & $\begin{array}{l}164(91.1 \\
\%)\end{array}$ & $\begin{array}{l}16(8.9 \\
\%)\end{array}$ & 1 & & 1 & \\
\hline \multicolumn{7}{|c|}{ Substance use } \\
\hline Yes & $\begin{array}{l}46(41.4 \\
\%)\end{array}$ & $\begin{array}{l}65(58.6 \\
\%)\end{array}$ & $\begin{array}{l}14.71(7.87, \\
27.47)\end{array}$ & 0.000 & $\begin{array}{l}2.54(0.49, \\
13.12) \\
\end{array}$ & 0.26 \\
\hline No & $\begin{array}{l}177(91.2 \\
\%)\end{array}$ & $\begin{array}{l}17(8.8 \\
\%)\end{array}$ & 1 & & 1 & \\
\hline \multicolumn{7}{|c|}{ Disease duration } \\
\hline$<1$ year & $\begin{array}{l}35(74.5 \\
\%)\end{array}$ & $\begin{array}{l}12(25.5 \\
\%)\end{array}$ & $1.14(0.42,3.08)$ & 0.79 & $\begin{array}{l}0.81(0.12, \\
5.18)\end{array}$ & 0.83 \\
\hline 1-5 years & $\begin{array}{l}76(73.1 \\
\%)\end{array}$ & $\begin{array}{l}28(26.9 \\
\%)\end{array}$ & $1.22(0.51,2.90)$ & 0.64 & $\begin{array}{l}0.63(0.12, \\
3.33)\end{array}$ & 0.59 \\
\hline 6-10 years & $\begin{array}{l}82(71.3 \\
\%)\end{array}$ & $\begin{array}{l}33(28.7 \\
\%)\end{array}$ & $1.34(0.57,3.13)$ & 0.49 & $\begin{array}{l}0.41(0.07, \\
2.15) \\
\end{array}$ & 0.29 \\
\hline$>10$ years & $\begin{array}{l}30(76.9 \\
\%)\end{array}$ & $\begin{array}{l}9(23.1 \\
\%)\end{array}$ & 1 & & 1 & \\
\hline \multicolumn{7}{|c|}{ Treatment duration } \\
\hline$<1$ year & $38(79.2$ & $10(20.8$ & 1 & & 1 & \\
\hline
\end{tabular}




\begin{tabular}{|c|c|c|c|c|c|c|}
\hline & $\%)$ & $\%)$ & & & & \\
\hline 1-5 years & $\begin{array}{l}85(73.3 \\
\%)\end{array}$ & $\begin{array}{l}31(26.7 \\
\%)\end{array}$ & $1.38(0.61,3.11)$ & 0.42 & $\begin{array}{l}2.22(0.13, \\
38.0)\end{array}$ & 0.58 \\
\hline 6-10 years & $\begin{array}{l}78(69.6 \\
\%)\end{array}$ & $\begin{array}{l}34(30.4 \\
\%)\end{array}$ & $1.65(0.74,3.70)$ & 0.21 & $\begin{array}{l}0.70(0.04 \\
12.36) \\
\end{array}$ & 0.81 \\
\hline$>10$ years & $\begin{array}{l}22(75.9 \\
\%)\end{array}$ & $\begin{array}{l}7(24.1 \\
\%)\end{array}$ & $1.20(0.40,3.63)$ & 0.73 & $\begin{array}{l}0.52(0.03 \\
9.22) \\
\end{array}$ & 0.65 \\
\hline \multicolumn{7}{|c|}{$\begin{array}{l}\text { Knowledge about HIV and its } \\
\text { treatment }\end{array}$} \\
\hline Knowledgeable & $\begin{array}{l}181(90.0 \\
\%)\end{array}$ & $\begin{array}{l}20(10.0 \\
\%)\end{array}$ & 1 & & 1 & \\
\hline Not knowledgeable & $\begin{array}{l}42(40.4 \\
\%)\end{array}$ & $\begin{array}{l}62(59.6 \\
\%)\end{array}$ & $\begin{array}{l}13.36(7.29 \\
24.47)\end{array}$ & 0.000 & $\begin{array}{l}8.13(3.06, \\
21.61) \\
\end{array}$ & $0.000 *$ \\
\hline \multicolumn{7}{|c|}{ Side effect of ARV drugs } \\
\hline Yes & $\begin{array}{l}44(38.6 \\
\%)\end{array}$ & $\begin{array}{l}70(61.4 \\
\%)\end{array}$ & $\begin{array}{l}23.7(11.83, \\
47.57)\end{array}$ & 0.000 & $\begin{array}{l}5.62(2.11 \\
14.93) \\
\end{array}$ & $0.001 *$ \\
\hline No & $\begin{array}{l}179(93.7 \\
\%)\end{array}$ & $\begin{array}{l}12(6.3 \\
\%)\end{array}$ & 1 & & 1 & \\
\hline \multicolumn{7}{|c|}{$\begin{array}{l}\text { comorbidity of other chronic } \\
\text { illness }\end{array}$} \\
\hline Yes & $\begin{array}{l}35(37.6 \\
\%)\end{array}$ & $\begin{array}{l}58(62.4 \\
\%)\end{array}$ & $\begin{array}{l}12.98(7.14 \\
23.58)\end{array}$ & 0.000 & $\begin{array}{l}5.46(1.86, \\
16.02) \\
\end{array}$ & $0.002 *$ \\
\hline No & $\begin{array}{l}188(88.7 \\
\%)\end{array}$ & $\begin{array}{l}24(11.3 \\
\%)\end{array}$ & 1 & & 1 & \\
\hline \multicolumn{7}{|l|}{ Waiting time } \\
\hline$<30$ minutes & $\begin{array}{l}140(75.3 \\
\%)\end{array}$ & $\begin{array}{l}46(24.7 \\
\%)\end{array}$ & 1 & & 1 & \\
\hline$>/=30$ minutes & $\begin{array}{l}83(69.7 \\
\%)\end{array}$ & $\begin{array}{l}36(30.3 \\
\%)\end{array}$ & $1.32(0.79,2.20)$ & 0.28 & $\begin{array}{l}0.67 \text { (0.24, } \\
1.87) \\
\end{array}$ & 0.45 \\
\hline \multicolumn{7}{|c|}{ Family disclosure status } \\
\hline Yes & $\begin{array}{l}184(88.9 \\
\%)\end{array}$ & $\begin{array}{l}23(11.1 \\
\%)\end{array}$ & 1 & & 1 & \\
\hline No & $\begin{array}{l}39(39.8 \\
\%)\end{array}$ & $\begin{array}{l}59(60.2 \\
\%)\end{array}$ & $\begin{array}{l}12.10(6.68 \\
21.89)\end{array}$ & 0.000 & $\begin{array}{l}5.27(2.20, \\
12.62)\end{array}$ & $0.000 *$ \\
\hline
\end{tabular}

Notes * shows significant at $P$-value $<0.05$

Figures 


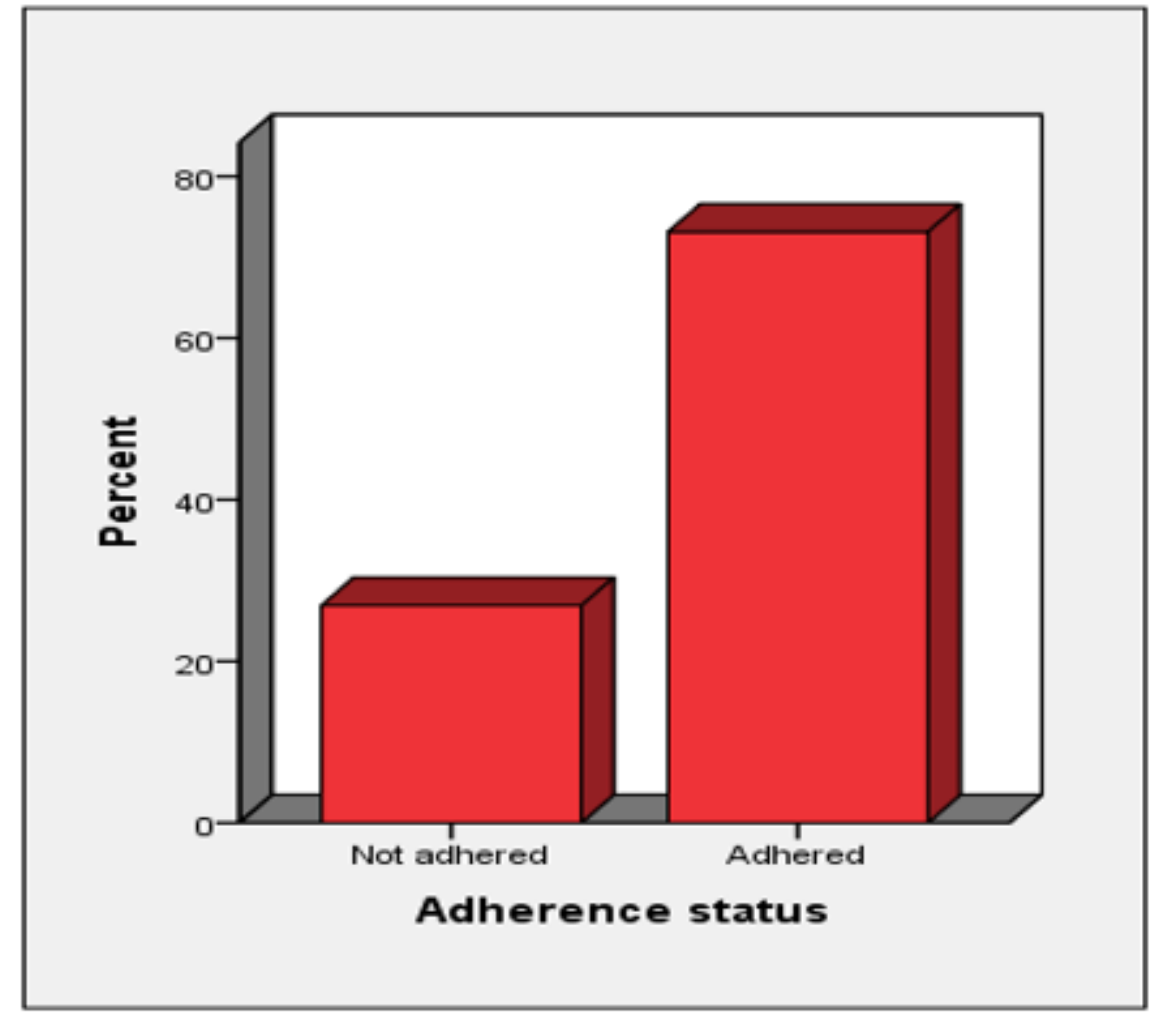

Figure 1

Bar graph showing the level of adherence to antiretroviral medication among HIV/AIDS patients at Nekemte referral hospital, West Ethiopia, 2019 